\title{
ANALISIS SISTEM HEAT RACE NET PLANT (NPHR) DI NII TANASA PADA PEMBANGKIT TENAGA UAP DENGAN KAPASITAS 2 x10 MW
}

\author{
Kadir $^{1}$, La Hasanudin ${ }^{2}$, Al Ichlas Imran ${ }^{3}$, Agustinus Lolok ${ }^{4}$, Aminur ${ }^{5}$, Salimin ${ }^{6}$, Yuspian \\ Gunawan $^{7}$, Abd Kadir ${ }^{8}$, Citra Yusnidar Syah'. \\ 1,2,3,5,6,7,8,9 Teknik Mesin Universitas Halu Oleo \\ ${ }^{4}$ Teknik Elektro Universitas Halu Oleo \\ 1irkadir69@gmail.com \\ 22La.hasanudin@uho.ac.id
}

\begin{abstract}
ABSTRAK
Net heat plant race (NPHR) adalah jumlah energi input yang dibutuhkan untuk menghasilkan energi listrik dari pembangkit, semakin tinggi nilai NPHR, semakin rendah efisiensi termal pembangkit listrik tenaga uap. Penelitian ini bertujuan untuk menganalisis nilai perlombaan panas pembangkit listrik netto (NPHR) dari pembangkit listrik tenaga uap. Metode yang digunakan dalam penelitian ini adalah dengan menggunakan metode Direct(Langsung), yaitu bahan bakar akan dibandingkan langsung dengan energi output yang dihasilkan. Hasil penelitian menunjukkan Net Race Heat Value (NPHR) Nilai rata-rata 4.986,87 kkal / kWh pada Januari 2018 dan nilai rata-rata 5.080,40 kkal / kWh pada Juni 2018. Ini menunjukkan bahwa nilai tersebut relatif tinggi untuk kapasitas daya $\leq 100 \mathrm{MW}$.
\end{abstract}

Kata kunci: NPHR, kWh, Energi, Tenaga uap, Pembangkit

\section{ABSTRACT}

\begin{abstract}
Analysis Of Heat Race Net Plant (NPHR) System In Nii Tanasa In Steam Power Generator With $2 \times 10 \mathrm{MW}$ Capacity. Net heat plant race (NPHR) is the amount of input energy needed to produce electrical energy from a generator, the higher the NPHR value, the lower the thermal efficiency of a steam power plant. This study aims to analyze the value of the heat race of net electricity generation (NPHR) from steam power plants. The method used in this research is to use the Direct method, where the fuel will be compared directly with the output energy produced. The results showed an average Net Race Heat Value (NPHR) of 4,986.87 kcal / kWh in January 2018 and an average value of 5,080.40 kcal / $\mathrm{kWh}$ in June 2018. This shows that the value is relatively high for a power capacity of $\leq 100 \mathrm{MW}$.
\end{abstract}

Keywords: NPHR, kWh, Energy, Steam power, Generators

\section{PENDAHULUAN}

Energi dapat berubah bentuk energi menjadi bentuk lain, atau menjadi pekerjaan yang bermanfaat. Secara keseluruhan, banyak bentuk untuk mengubah energy/ memasok dan menggunakan energi hanya mengambil sebagian pandangan dari rantai konversi energi, dan tidak mempertimbangkan efek, atau biaya, yang akan diubah oleh pasokan energi lengkap. Penggunaan sistem energi termal 'aktif dan pasif' untuk aplikasi ini dapat memberikan pengurangan signifikan dalam kebutuhan sumber energi primer yang bukan terbarukan. Dalam semua proses, reversibel atau ireversibel, perubahan energi internal harus sesuai dengan hukum termodinamika pertama. Perpindahan panas diklasifikasikan luas atau intensif. Perpindahan panas sangat luas jika nilainya untuk seluruh sistem adalah jumlah nilainya untuk berbagai bagian sistem perpindahan panas dengan jumlah panas pada pemancar per jam (biasanya per detik) (T) [1] [2], [3] [4], [5].

Pada Penelitian sebelumnya yang berkaitan dengan NPHR effisiensi termal pada boiler, Analisa heat rate 
system pada Nii Tanasa, effisiensi thermal pada turbin uap, tetapi ada perbedaan yang cukup signifikan dengan penulis lakukan karena menyangkut Nilai panas dalam pemilihan bahan bakar yang digunakan sehingga dalam suatu system pembakaran awal dapat terkontrol nilai efesiensinya pada pembangkit listrik tenaga uap, yang pada intinya terjadi keseimbangan out put bahan bakar yang digunakan dengan nilai daya yang dihasilkan dalam system Pembangkit Listrik Tenaga Uap [6], [7].

Permasalahan yang dihadapi dalam kajian ini adalah efektifitas pemakaian bahan bakar bruto dan bahan bakar netto, sehingga dalam analisanya perlu mengkaji lebih dalam keseimbangan input bahan bakar dengan yang dihasilkan oleh suatu pembangkit listrik tenaga uap. Proses memanaskan air untuk menghasilkan uap adalah fenomena yang lazim. Net Heat Heat Race (NPHR) adalah jumlah bahan bakar atau energi panas yang masuk ke boiler yang digunakan untuk menghasilkan energi listrik $1 \mathrm{kWh}$ atau $\mathrm{Kj} / \mathrm{kWh}$ atau kcal / $\mathrm{kWh}$. Net heat race plant (NPHR) digunakan sebagai dasar untuk menentukan jumlah bahan bakar dalam studi kelayakan finansial. Untuk pembangkit listrik tenaga uap berbahan bakar batubara. Semakin besar nilai Heat Rate, semakin buruk efisiensi generator, dan sebaliknya semakin kecil nilai Heat Rate, semakin efisien generator. Kualitas batubara di PLTU akan memengaruhi efisiensi boiler. Terutama total kelembaban dan kandungan hidrogen batubara sebagai kontributor terbesar hilangnya basah di boiler. Kebaruan dari penelitian ini adalah dapat menganalisa nilai NPHR (Net Plant Heat race).dengan direct method analysis, sehingga lebih mudah dalam menentukan nilai NPHR . Secara umum, kenaikan NPHR yang sebenarnya dibandingkan dengan NPHR ketika commissioning TMCR (Turbine Maximum Continues Rate) disebabkan oleh penurunan kinerja unit [8] [9] [10].

Penelitian ini bertujuan untuk menentukan analisis, perpindahan panas NetPlant (NPHR) bulanan. Analisis karakteristik beban dan analisis perpindahan panas pada NPHR sangat penting. Pembangkit listrik tenaga uap NiiTanasa adalah pembangkit listrik dengan kapasitas $3 *$ 10 MW menggunakan bahan bakar batubara. Dalam generator sangat terkait dengan fluktuasi beban dalam bentuk harian, bulanan atau tahunan, serta berkaitan dengan Net Heat Race (NPHR) untuk menganalisis panas yang dihasilkan dari pembakaran batubara, jumlah bahan bakar yang digunakan, daya yang dihasilkan oleh generator, jadi berdasarkan ini, peneliti tertarik untuk meneliti

\section{METODE}

Metode yang digunakan dalam penelitian ini adalah: menggunakan metode Direct, yaitu bahan bakar yang digunakan dalam generator, akan dibandingkan secara langsung dengan energi output yang dihasilkan oleh generator. Dimana data yang digunakan bersumber dari data sekunder Pembangkit listrik tenaga uap di NiiTanasa dengan kapasitas 2 x10 Mega watt. Penelitian ini dilakukan pada bulan Juli 2019 di Nii Tanasa Kecamatan Soropia Kabupaten Konawe .

Adapun tahapan atau Langkah-langkah dalam penelitian ini ialah:

a) Dilakukan survey awal di lokasi penelitian

b) Dilakukan tahapan administrasi ke lokasi kegiatan ke PT.PLN(Persero) Cabang Kendari

c) Pengambilan data yang diperlukan

d) Data dianalisa dengan menggunakan formula. Perhitungan Net Heat Heat Race (NPHR) menggunakan rumus berdasarkan SPLN nomor 80 pada tahun 1989 dengan persamaan 1 .

$N P H R=\frac{q f * L H F}{k W h_{N e t t o}}$

Dimana:

$1 \mathrm{kWh}=860$ kalori berat.

NPHR = Laju panas bersih (kcal $/ \mathrm{kWh})$.

Qf = Jumlah bahan bakar yang digunakan ( $\mathrm{kg})$.

LHF = nilai kalori bahan bakar $(\mathrm{kkal} / \mathrm{kg})$.

\section{HASIL DAN PEMBAHASAN}

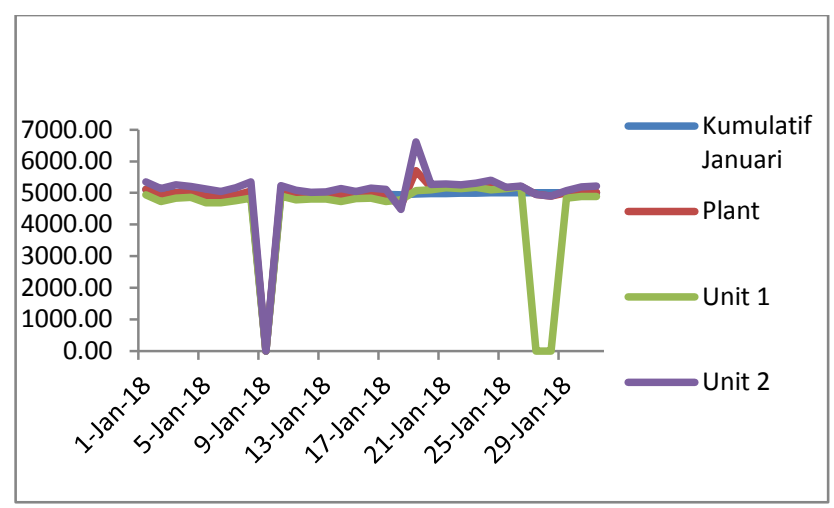

Gambar .1 NPHR (kcal / kWh) nilai pada bulan Januari

Berdasarkan gambar 1 menunjukan Nilai Net Heat Heat Race (NPHR), ketika generator mengekspor daya atau beban pada generator Unit 1 diperoleh nilai tertinggi pada 1 Januari adalah 4.940,74 kkal / kWh, sedangkan nilai terendah adalah pada $(9,27,28)$ Januari sama dengan 0 kkal / kWh. Nilai rata-rata adalah 4.899,95 kkal / kWh. 
Untuk tanggal $(9,27,28) 0$ Januari kkal / kWh disebabkan oleh tidak ada pengambilan data pada hari itu. Di Unit 2 skor tertinggi pada 19 Januari adalah 6.614,20 kkal / kWh, sedangkan skor terendah pada 9 Januari adalah 0 kkal / kWh. Nilai rata-rata adalah 5,193.24 kkal / kWh ... Untuk 9 Januari 0 kkal / $\mathrm{kWh}$ karena tidak ada pengambilan data pada hari itu. Nilai tertinggi dari Plant Unit 1 dan 2 pada 19 Januari adalah 5.702,04 kkal / kWh, sedangkan nilai terendah pada 9 Januari adalah 0 kkal / $\mathrm{kWh}$. Nilai rata-rata adalah 5.032,33 kkal / kWh. Untuk 9 Januari, 0 kkal / kWh disebabkan oleh tidak ada pengambilan data pada hari itu. Nilai kumulatif tertinggi dari Unit 1 dan 2 pada tanggal 1 Januari adalah 5.116,40 kkal / kWh.Sedangkan skor terendah pada bulan Januari adalah $0 \mathrm{kkal} / \mathrm{kWh}$, nilai rata-rata adalah 4.986,87 kkal / kWh. Untuk 9 Januari, 0 kkal / kWh. karena tidak ada pengambilan data pada hari itu. Hal ini sejalan dengan yang dilakukan oleh peniliti [7] bahwa tingkatan operasional bahan bakar, masih dalam batas yang wajar dan layak operasi.

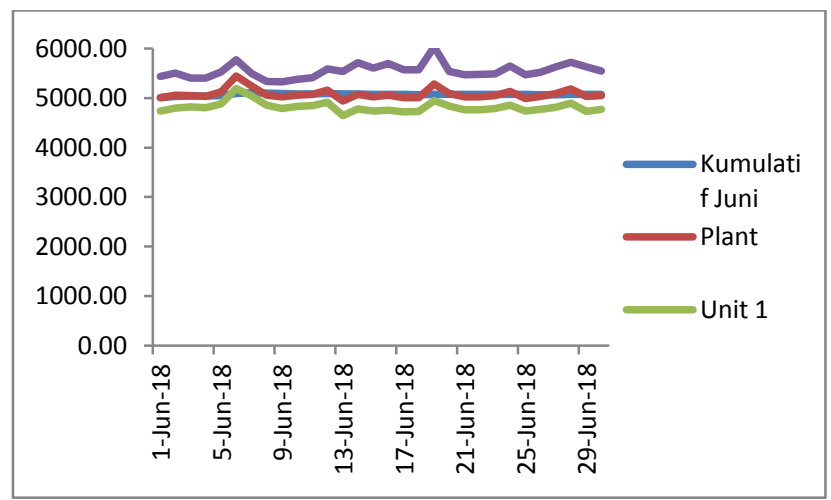

Gambar.2.Nilai NPHR bulan Juni

Berdasarkan gambar 2 memperlihatkan Nilai Net Heat Heat Race (NPHR), ketika generator mengekspor daya atau beban pada generator Unit 1 diperoleh nilai tertinggi pada 6 Juni adalah 5.193,00 kkal / kWh, sedangkan nilai terendah pada 6 Juni adalah 4.643,81 kkal / kWh Nilai rata-rata adalah 4.817,55 kkal / $\mathrm{kWh}$. Di Unit 2, skor tertinggi pada 19 Juni adalah 6.035,29 kkal / kWh, sedangkan nilai terendah pada 9 Juni adalah 5.329,18 kkal / kWh. Nilai rata-rata adalah 5.547,30 kkal / kWh. Nilai tertinggi Plant Unit 1 dan 2 pada 6 Juni adalah 5.447,80 kkal / kWh, sedangkan nilai terendah pada 13 Juni adalah 4.935,28 kkal / kWh. Nilai rata-rata adalah 5.080,40 kkal / kWh. Nilai kumulatif tertinggi dari Unit 1 dan 2 pada 7 Juni adalah 5.106,00 kkal / kWh, sedangkan nilai terendah pada Juni adalah 5.006,71 kkal / kWh. Nilai ratarata adalah 5.070,10 kkal / $\mathrm{kWh}$. Hal ini sejalan dengan penelitian yang dilakukan oleh peneliti [6], bahwa batas maksimun tingkat panas yang ada pada Pembangkit listrik tenaga uap di Nii Tanasa masih dalam kategori layak operasi.

\section{KESIMPULAN}

Nilai NPHR (Net Plant heat race) pada bulan januari 4.986,87 kkal / kWh., sedangkan pada bulan juni nilai rata-rata NPHR Nilai rata-rata adalah 5.070,10 kkal / kWh. "berdasarkan batas NPHR diusulkan oleh Generator listrik Negara (PLN) masih dalam batas standar operasi

\section{DAFTAR PUSTAKA}

[1] Evans, Fueling Our Future an introduction to sustainable energy, United satate of America : Cambridge University press, 2007.

[2] P.Bloch, Turbines, Design, Applications, and rerating, Fransisco,Lisbon, London, Madrid, Mexico city, Milan, New Dehli, San Juan Seoul, Singapur, Sidney, Toronto: MC.Grawhill, 2009.

[3] s. Stolen, Chemical Thermodynamics of Materials, Norway,UK: John Wiley and Sons,Ltd, 2004.

[4] C. Wiu, Thermodynamics and heat Powered cycles a cognitive Enggineering approach, New York: Nova Science publishers,inch, 2007.

[5] Kutz, Heat Transfer Calculations, United of America: Mc Graw-Hill,inc, 2006.

[6] Adnal, "Analisis Efisiensi Thermal PLTU Nii Tanasa dengan memakai bahan bakar rendah kalori berkapasitas 20*MW," Pendidikan Fisika PLTE FKIP UHO, Kendari, 2018.

[7] L. Hasanudin, "Thermal efficiency analysis on the steam power Plant in Nii Tanasa by using a two semester direct method with a Capacity of 2 x10 MW," Jurusan Teknik Elektro Fakultas Teknik Universitas Halu Oleo, Kendari, 2019. 
[8] Cahyadi, "Pembangkit Listrik Batu bara super kritikal yang efesien," B2TE-BPPT, Tangerang Selatan, 2015.

[9] A. Qadir, 2015. [Online]. Available: http://aabdulqadir.wordpress.com/2015/01/10/h eat-rate-power-Plant/,2015.

[10] https://www.linkedin.com/pulse/mengaparealisasi-kinerja-nphr-nett-plant-heat-ratelistrik-wibowo, "mengapa-realisasi-kinerjanphr-nett-plant-heat-rate-listrik," Linked in, Indonesia, 2018.

[11] W. D. Callister, Fundamentals of Materials Science and Engineering, New York: John Willey \& Sons, Inc., 2001.

[12] D. Chapelle and K. J. Bathe, The Finite Element Analysis of Shells-Fundamentals, Berlin: Springer, 2011. 